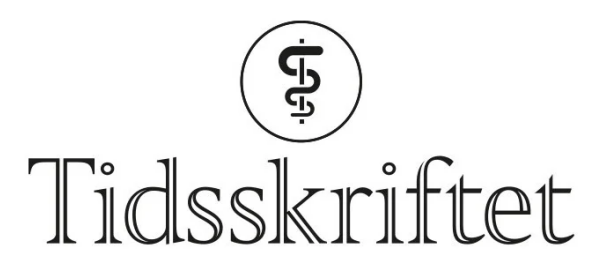

DEN NORSKE LEGEFORENING

\title{
Grundig om fosterdiagnostikk
}

\author{
ANMELDELSER
}

BENEDICTE PAUS

Benedicte Paus er spesialist i medisinsk genetikk, overlege ved Avdeling for medisinsk genetikk, Oslo universitetssykehus, og professor ved Institutt for klinisk medisin, Universitetet i Oslo.

Bjørn M. Hofmann, Eivor A. Oftestad, Morten Magelssen

Hva vil vi med fosterdiagnostikken?

Fosterdiagnostikkens etikk. 188 s, tab, ill. Oslo: Cappelen Damm Akademisk, 2021. Pris NOK 329

ISBN 978-82-02-69399-2

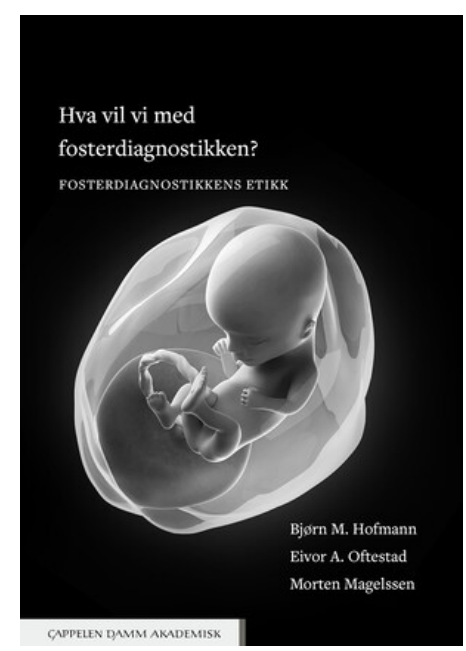

Etter en redegjørelse for kontekst, definisjoner og metoder får leseren en historisk gjennomgang av fosterdiagnostikken, som ender opp i dagens politiserte diskusjon og endringer i retningslinjene i 2020. Flere kapitler omhandler systematiske etikkfaglige drøftinger om dagens - og forfatternes tanker om fremtidens - diagnostikk.

Den historiske oversikten er spennende og belyses med sitater fra fagfolk og politikere. Teknologi synes i liten grad å ha påvirket etiske kjernespørsmål, som ble reist lenge før dagens metoder var tilgjengelige. Både eugeniske holdninger og holdningen om at alle 
mennesker har lik verdi og at samfunnet bør tilrettelegge bedre for funksjonshemmede, ble tydelig uttrykt for over 50 år siden. Samtidig mener forfatterne at fosterdiagnostikken er styrt av teknologi.

Dagsaktuell som den er, kan boken ha blitt laget raskt. Setningene er stedvis tunge, og noen tabeller har for mye tekst. Det er misvisende når måter å innhente DNA fra fosteret på (som ved fostervannsprøve) blir kalt tester.

Det er størst fokus på screening for nyoppståtte utviklingsavvik. Screeningmetoder for Downs syndrom presenteres som diagnostiske tester med falskt positive og falskt negative prøvesvar. Noen vil være uenige i denne forståelsen av screening, som per definisjon kun skal påvise økt sannsynlighet. Uansett er diskusjonen om screening for denne ene genetiske tilstanden i alle graviditeter tankevekkende. Alvorlige og fremadskridende arvelige sykdommer er lite nevnt, men kunne ha illustrert at formålet med fosterdiagnostikk også kan være å unngå at det blir født barn som med høy sannsynlighet vil måtte gjennomgå store lidelser.

I kapitlet om fremtidens fosterdiagnostikk omtales helgenomsekvensering som «full kartlegging av fosterets gener». Helgenomsekvensering gir imidlertid ingen full kartlegging av sykdom og egenskaper, og mulige følger av usikre funn og genetisk determinisme kunne vært mer omtalt.

Med sine etiskfaglige analyser er boken lærerik for leger. Den er skrevet av noen av våre fremste medisinske etikere, som er aktive i den offentlige debatten og har stor kunnskap. De presenterer mindre brukte poeng, som at fosterdiagnostikken er regulert og organisert som en helsetjeneste, men ofte forstås som en sosial- eller velferdstjeneste. Og at mantraet om kvinnens selvbestemmelsesrett kan være et argument for selvbestemt abort, men ikke nødvendigvis for fosterdiagnostikk, da det førstnevnte handler om retten til å bestemme om man vil være gravid, og det siste om en ikke like selvsagt rett til å selektere barn ut fra antatte fremtidige egenskaper. Til sist besvarer forfatterne sitt eget spørsmål om formål med fosterdiagnostikken og forklarer hvorfor spørsmålet er så viktig å besvare.

Boken går dypt i problemstillingen og kan anbefales til leger, andre helsearbeidere, journalister og beslutningstakere.

Publisert:3. september 2021. Tidsskr Nor Legeforen. DOI: 10.4045/tidsskr.21.0521

(C) Tidsskrift for Den norske legeforening 2023. Lastet ned fra tidsskriftet.no 26. april 2023. 